\title{
PENGARUH AUDIT TENURE, REPUTASI KANTOR AKUNTAN PUBLIK, DAN KELENGKAPAN KERTAS KERJA PERMANEN TERHADAP KUALITAS AUDIT (STUDI KASUS PADA PERUSAHAAN LQ45 YANG TERDAFTAR DI BEI TAHUN 2009-2014)
}

\author{
Budi Supri Handoko \\ Program Akuntansi, Fakultas Ekonomi dan Bisnis, Universitas Bhayangkara Jakarta Raya \\ budihandoko663@yahoo.co.id
}

\begin{abstract}
This study examines the influence of tenure and reputationof public accounting firms and thecompleteness of the permanent working paper on quality auditing. This study is focused on LQ 45 company that has been listed on The Indonesia Stock Exchangeduring 2009 until 2014. Moreover, by using a purposive sampling metode is gained 234 research samples. The hypothesis testing in this study is using multiple regression analysis. The test results indicate that audit tenure has no effect to the quality of the audit, the reputation of public accountant to audit quality while the completeness of paper work does not affect the quality of the audit
\end{abstract}

Keywords: Audit Quality, Tenure, KAP's Reputation, The Permanent Working Paper

\begin{abstract}
ABSTRAK
Penelitian ini menguji mengenai pengaruh audit tenure, reputasi kantor akuntan public dan kelengkapan kertas kerja permanen terhadap kualitas audit. Peneltian ini di fokuskan pada perusahaan LQ 45 yang terdaftar di Bursa Efek Indonesia tahun 2009 sampai dengan 2014, dengan mengggunakan metunakan metode purposive sampling diperoleh 234 sampel penelitian. Pengujian hipotesis dalam penelitian ini menggode purposive sampling diperoleh 234 sampel penelitian. Pengujian hipotesis dalam penelitian ini menggunakan analisis regresi berganda. Hasilpengujian menunjukkan bahwa audit tenure tunakan analisis regresi berganda. Hasilpengujian menunjukkan bahwa audit tenure tidak berpengaaruh terhadap kualitaas audit, reputasi berpengaruh terhadap kualitas audit sedangkan kelengkapan kertas kerjatidak berpengaruh terhadap kualitas audit.
\end{abstract}

Kata Kunci: Kualitas Audit, Tenure, Reputasi KAP, Kertas Kerja Permanen

\section{PENDAHULUAN}

Peranan kantor akuntan publik saat ini semakin luas tidak hanya bertujuan untuk memberikan laporan keuangan dan pendapat dalam bentuk opini kepada pihak internal (manajemen perusahaan \& pemegang saham) 
dan eksternal perusahaan (pemerintah), namun peran akuntan publik di minta dapat berperan lebih seiring perkembangan kegiatan bisnis dan ekonomi di Indonesia, misalnya saja dalam peraturan OJK (Otoritas Jasa Keuangan) nomor 5/POJK.05/2014 tentang "Perizinan Usaha" yang mengharuskan laporan keuangan perusahaan diaudit oleh kantor akuntan publik untuk memperoleh izin dari Otoritas Jasa Keuangan (OJK) sebagai perusahaan go publik. Peraturan lainnya oleh Bank Indonesia (BI) nomor 14/15/PBI/2012 tentang "Penilaian Kualitas Aset Bank Umum" yang mewajibkan suatu bank memiliki ketentuan intern agar sebuah perusahaan diaudit untuk mengetahui kondisi keuangan yang sebenarnya serta kesinambungan usahanya (Going Concern) sebagai salah satu persyaratan yang diberikan kepada perusahaan untuk mendapatkan pinjaman Kredit Modal Kerja (KMK). Kemudian pada peraturan Bank Indonesia No.15/3/PBI/2013 tentang “Transparansi Kondisi Keuangan Bank Perkreditan Rakyat" yang mewajibkan Bank Perkreditan Rakyat (BPR) yang memiiki asset lebih besar dari atau sama dengan Rp 10.000.000.000 (sepuluh milyar) untuk diaudit oleh akuntan publik, berdasarkan penjelasan dan regulasi diatas dapat disimpulkan bahwa peranan dan fungsi sebuah kantor akuntan publik sangat penting dalam menilai sebuah laporan keuangan suatu perusahaan secara objektif dan transparan dalam memberikan opini atas laporan keuangan. Akuntan publik juga dituntut untuk bekerja lebih professional dan independen, sebab opini dan laporan audit yang dikeluarkan sebuah kantor akuntan publik memiliki dampak yang luas dan digunakan sebagai dasar acuan oleh pengguna laporan keuangan baik pihak internal (manajemen perusahaan, dan pemegang saham) maupun eksternal (pemerintah) dalam mengambil keputusan.

Fenomena tentang kertas kerja pemeriksaan dan dokumen pernah terjadi di Amerika Serikat pada kasus enron, kasus ini ikut menyeret kantor akuntan publik besar saat itu atau disebut the big five (KAP Arthur Anderson) sehingga membuat akuntan publik kehilangan kepercayaan dimata publik (masyarakat) dan membuat pemerintah Amerika Serikat ikut turun tangan dalam membantu menyelesaikan masalah saat tersebut. Enron merupakan perusahaan yang bergerak dalam bidang industri energi kemudian melakukan diversifikasi usaha yang sangat luas meliputi future transaction, trading commodity non energy dan kegiatan bisnis keuangan. Enron merupakan perusahaan terbesar dan menempati peringkat 7 besar dari 500 perusahaan terkemuka di Amerika Serikat, kasus ini banyak diangkat oleh para akuntan dan penulis salah satunya oleh Winter (2009) dalam jurnal The Enron Collapse - The Aftershcoks yang menjelaskan tentang pasca terjadinya kasus enron dan tindakan yang dilakukan oleh pemerintah Amerika Serikat, dijelaskan bahwa KAP Arthur Anderson telah melakukan pelanggaran dan penipuan dengan membuat pendapatan perusahaan secara fiktif, menyembunyikan dan tidak melaporkan hutang dan kerugian serta menghancurkan dokumen-dokumen penting lain dan kertas kerja pemeriksaan audit (permanent \& current) sehingga pasca terjadinya kasus enron di Amerika serikat, dibuatlah undang-undang oleh pemerintah Amerika Serikat (Sarbanes Oxley) yang memberikan sanksi hukuman pidana kepada akuntan yang melanggar etika dan hukum. Peraturan (Sarbanes Oxley) ayat 802 menjatuhkan hukuman denda dan penjara selama 20 tahun apabila terbukti memanipulasi, menyembunyikan dokumen dan catatan, serta mewajibkan akuntan untuk membuat kertas kerja pemeriksaan.

Baru ini pemerintah bersama DPR (Dewan Perwakilan Rakyat) telah mengesahkan peraturan undang undang No. 5 tahun 2011 tentang akuntan publik yang memberikan sanksi pidana bagi akuntan yang melanggar kode etik profesi akuntan publik, di dalam undang-undang tersebut diantaranya memuat aturan tentang kertas kerja pemeriksaan dalam (pasal 25 ayat $2 \mathrm{c}$ ) yang mewajibkan semua kantor akuntan publik dalam memberikan jasanya membuat kertas kerja pemeriksaan.

Tidak konsistennya hasil penelitian mengenai audit tenure terhadap kualitas audit yang dilakukan penelitian diuraikan diatas, dan belum pernah dilakukannya penelitian mengenai kertas kerja permanen di bebeberapa objek penelitian (kantor akuntan publik) membuat peneliti tertarik untuk meneliti kembali mengenai kualitas audit dengan mereplikasi penelitian I Putu Nuratama (2011) yang meneliti pengaruh tenur dan reputasi kantor akuntan publik (KAP) terhadap kualitas audit dan penelitian Permana (2012) yang meneliti peranan kertas kerja permanen terhadap laporan audit (opini). 


\section{TINJAUAN PUSTAKA}

Laporan Keuangan merupakan obyek dari analisis terhadap laporan keuangan. Giri (2012:37) mengemukakan bahwa: "laporan keuangan adalah suatu penyajian terstruktur mengenai posisi keuangan dan kinerja keuangan suatu entitas, tujuan laporan keuangan adalah untuk memberikan informasi mengenai posisi keuangan, kinerja keuangan dan arus kas entitas yang bermanfaat bagi sebagian besar kalangan pengguna laporan dalam pembuatan keputusan ekonomi”.

Tujuan pemeriksaan atas laporan keuangan oleh auditor independen adalah untuk menyatakan pendapat atas kewajaran dalam semua hal yang material, posisi keuangan, hasil usaha, dan arus kas yang sesuai dengan prinsip akuntansi yang berlaku umum.

Audit program merupakan kumpulan dari prosedur - prosedur audit yang akan dijalankan dan dibuat secara tertulis. Audit program membantu auditor dalam memberikan perintah kepada asisten mengenai pekerjaan yang harus dilaksanakan. Audit program harus menggariskan dengan rinci, prosedur audit yang menurut keyakinan auditor diperlukan untuk mencapai tujuan audit. Audit program yang baik harus mencantumkan :

1) Tujuan pemeriksaan

2) Audit prosedur yang akan dijalankan

3) Kesimpulan pemeriksaan

Sebagian KAP menggunakan audit program yang sudah distandarisasi dan digunakan di setiap kliennya, sebagian lagi menggunakan audit program yang disusun dengan kondisi dan situasi di perusahaan (tailor made). Akan lebih baik jika audit program dibuat terpisah untuk compliance test dan substantive test.

Audit tenure adalah masa jabatan dari Kantor Akuntan Publik (KAP) dalam memberikan jasa audit terhadap kliennya. Ketentuan mengenai audit tenure telah dijelaskan dalam Keputusan Menteri Keuangan Republik Indonesia Nomor 359/KMK.06/2003 pasal 2 yaitu masa jabatan untuk KAP paling lama 5 tahun berturut-turut. Sementara itu, menurut seksi 203 Sarbanes Oxley Act of 2002 yang merupakan amandemen dari seksi 10A The Security Exchange Act of 1934 (15U.S.C. 78j - 1) membatasi auditor dalam memberikan jasa auditnya sampai dengan 5 tahun Pengaruh lama ikatan dengan klien terhadap kualitas audit sangat bertentangan. Beberapa penelitian menyebutkan bahwa lama ikatan dengan klien mereduksi independensi auditor dan objektifitas, dan oleh karena itu sebaiknya klien secara suka rela melakukan rotasi KAP, Adibowo (2009) menyatakan bahwa rotasi auditor itu akan meningkatkan kualitas audit dan independensi audit melalui suatu pengurangan pengaruh klien terhadap auditor, tetapi disisi lain ada yang beranggapan bahwa kualitas audit bertambah seiring dengan lamanya ikatan.

\section{METODE PENELITIAN}

Penelitian ini merupakan studi empiris (empirical studies) yaitu studi tentang fakta atau data yang nyata yang dikumpulkan dan di uji secara sistematis.

Populasi dalam penelitian ini adalah seluruh KAP (Kantor Akuntan Publik) di Jakarta untuk menguji pengaruh kertas permanen file terhadap kualitas audit dan laporan keuangan perusahaan manufaktur yang terdaftar di Bursa Efek Indonesia pada periode tahun 2009-2014 untuk menguji pengaruh tenure audit dan reputasi KAP terhadap kualitas audit.

Metode pengumpulan data yang dipergunakan dalam penelitian ini terdapat dua tehnik yaitu : 
1. Tehnik observasi (observation) Dalam metode ini pengumpulan data dilakukan dengan observasi/pengamatan dimana peneliti tidak terlibat langsung dengan aktivitas objek yang diteliti.

2. Tehnik survei, kuesioner Pengertian metode Angket adalah pernyataan tertulis yang digunakan untuk memperoleh informasi dari responden dalam arti laporan tentang pribadi atau hal-hal yang ia ketahui.

Pengukuran variabel-variabel yang digunakan dalam penelitian ini adalah sebagai berikut :

1. Kertas Kerja Permanen

Kertas kerja permanen adalah kertas kerja yang berisi kertas kerja yang mempunyai kegunaan untuk beberapa tahun misalnya : Akte pendirian, Buku pedoman akuntansi, kontrak-kontrak dan notulen rapat (Agoes, 2011). Kertas kerja permanen file diukur dengan melihat kelengkapan dan banyaknya (Volume) kertas kerja permanen file atas laporan audit, kemudian menilai kelengkapan kertas kerja permanen file berdasarkan ketentuan dan kriteria sesuai SPAP (Standar Professional Akuntan Publik).

2. Tenure KAP

Tenure KAP adalah masa jangka waktu perikatan yang terjalin antara KAP dengan auditee yang sama. Tenure KAP diukur dengan menghitung tahun dimana KAP yang sama telah melakukan perikatan dengan auditee dalam batas regulasi yang telah ditentukan oleh pemerintah.

3. Reputasi KAP

Reputasi KAP dalam penelitian ini diukur dengan menggunakan kelompok auditor big four dan non big four. Auditor big four identik dengan KAP besar, Efraim (2010) mengatakan bahwa KAP besar identik dengan KAP bereputasi tinggi. Reputasi KAP diukur dengan menggunakan variabel dummy, yaitu diberikan kode 1 jika KAP berafiliasi dengan KAP Big Four, dan diberikan kode 0 jika KAP tidak berafiliasi dengan KAP Big Four.

4. Kualitas audit

Myers et al (2003) berpendapat bahwa ukuran akuntansi akrual adalah descriptor yang masuk akal untuk kualitas audit. Pendapat tersebut diperoleh dengan menghubungkan antara kualitas laba dengan kualitas audit. Diperoleh hasil bahwa tingkat akrual yang tinggi berhubungan positif dengan auditor litigation, isu mengenai opini audit qualified, kegagalan audit dan pergantian

auditor, sedangkan tingkat akrual yang rendah berhubungan dengan konservatisme auditor yang tinggi, yang dapat diusulkan sebagai tingginya kualitas audit (Myers et.al, 2003). Kualitas audit dalam penelitian ini diukur dengan menggunakan akrual lancar (current accual) sesuai dengan yang digunakan oleh Myers et.al (2003), Efraim (2010) dan Nuratama (2011) yang dihitung dengan menggunakan rumus sebagai berikut.

AKRUALLANCAR $=(\Delta$ AL- $\Delta$ KAS $)-(\Delta L L-\Delta L J P)$

Keterangan:

$\triangle \mathrm{AL} \quad=$ Perubahan asset lancar

$\triangle \mathrm{KAS}=$ Perubahan kas dan ekuivalen kas

$\Delta \mathrm{LL} \quad=$ Perubahan liabilitas lancar

$\Delta \mathrm{LJP}=$ Perubahan dalam utang wesel jangka pendek dan utang jangka

panjang yang akan jatuh tempo

\section{HASIL PENELITIAN DAN PEMBAHASAN}

Hasil pengujian hipotesis menunjukkan bahwa tenure KAP tidak berpengaruh pada kualitas audit. Hasil penelitian ini konsisten dengan hasil penelitian Wibowo dan Rossieta (2009) yang menyatakan bahwa masa penugasan tidak berpengaruh terhadap kualitas audit hasil penelitian ini juga mendukung penelitian Carey dan Simnett (2006) yang menyatakan bahwa tenure audit yang panjang tidak berhubungan terhadap kualitas audit.

Hasil pengujian hipotesis menunjukkan bahwa reputasi KAP berpengaruh terhadap kualitas audit. Hasil pengujian ini berarti bahwa KAP yang berafiliasi asing atau Big - 4 berpengaruh terhadap kualitas audit, Hasil 
ini tidak sependapat dengan hasil penelitian Efraim (2010) yang menemukan bahwa reputasi KAP yang diukur dengan KAP yang berafilisasi dengan KAP internasional tidak berpengaruh terhadap kualitas audit. Pengaruh reputasi KAP (Kantor Akuntan Publik) terhadap kualitas audit dikarenakan semakin besar KAP (Kantor Akuntan Publik) atau kantor akuntan dengan reputasi yang baik akan memiliki auditor-auditor (Sumber Daya Manusia) yang lebih berkualitas dengan sering mengadakan training (pelatihan-pelatihan) di internal atau eksternal, kemudian semakin baik reputasi KAP (Kantor Akuntan Publik) maka jumlah auditor (anggota team) yang diikutsertakan dalam penugasan audit juga lebih banyak dibandingkan dengan Kantor Akuntan Publik (KAP) non big - 4. Sehingga hasil audit yang dihasilkan akan semakin baik dan berkualitas

Hasil pengujian hipotesis menunjukkan bahwa kertas kerja permanen tidak berpengaruh terhadap kualitas audit. Hasil ini tidak mendukung dengan hasil penelitian Eka Permana (2012) yang menyatakan bahwa kertas kerja permanen berpengaruh terhadap laporan audit (opini audit). Hal ini di karenakan kertas kerja permanen mayoritas (jumlah paling banyak) berisi perjanjian-perjanjian antara pihak pertama dan kedua seperti Akta Notaris, SIUP (Surat Ijin Usaha Perdagangan), perjanjian asuransi, polis asuransi, dan lain-lain pada umumnya kertas kerja permanen berisi perjanjian legalitas (perijinan) sehingga bukan seperti kertas kerja current file yang merupakan kertas kerja yang berisi pengujian-pengujian (pengujian substantif) dalam bentuk angka (nominal) yang dapat mengubah saldo dalam laporan keuangan (financial statement).

\section{KESIMPULAN DAN SARAN}

\section{Kesimpulan}

Berdasarkan hasil penelitian yang diperoleh melalui pengujian statistik serta pembahasan yang telah diuraikan pada bab sebelumnya, maka dapat disimpulkan hal-hal sebagai berikut.

1) Variabel tenure tidak berpengaruh pada kualitas audit yang berarti bahwa semakin lama KAP mengadakan perikatan audit kepada kliennya tidak menyebabkan kualitas auditnya menjadi semakin baik. Hal ini mendukung penelitian Wibowo dan Rossieta (2009) yang menyatakan masa penugasan tidak berpengaruh terhadap kualitas audit, dan penelitan Carey dan Simnett (2006) yang menyatakan bahwa tenure audit yang panjang tidak mempengaruhi kualitas audit. Hal ini dikarenakan konsistensi dan keutuhan anggota team yang melakukan audit tidak sama dengan keutuhan jumlah anggota team tahun sebelumnya (adanya anggota team atau incharge/ketua team yang dipindah tugaskan) sehingga mempengaruhi pemahaman bisnis klien (perusahaan) yang diaudit.

2) Variabel Reputasi KAP berpengaruh terhadap kualitas audit yang berarti hasil audit yang dilakukan KAP (Kantor Akuntan Publik) Big-4 memiliki kualitas audit yang baik. Hal ini dikarenakan KAP Big -4 memiliki program dan planning (perencanaan) audit yang lebih baik dan jumlah auditor (sumber daya manusia) yang jauh lebih banyak dibandingkan kantor akuntan non big - 4 sehingga mempengaruhi hasil audit.

3) Variabel Kertas Kerja Permanen tidak berpengaruh terhadap kualitas audit, Hasil ini tidak mendukung hasil penelitian Eka Permana (2012) yang menyatakan bahwa kertas kerja permanen berpengaruh terhadap laporan audit (opini audit). Hal ini dikarenakan kertas kerja permanen berisi pernyataan-pernyataan atau perjanjian yang bersifat legalitas (perijinan) seperti akta notaris, akta perubahan, ijin usaha (SIUP), perjanjian kredit bank, perjanjian pihak ketiga, dll sehingga tidak mempengaruhi hasil audit.

\section{Saran}

Dari hasil penelitian dan kesimpulan diatas tersebut, maka dibawah ini dapat disajikan beberapa saran yang berguna :

1) Penelitian ini memiliki kelemahan yakni karena proksi kualitas audit pada penelitian ini bukanlah ukuran aktual yang digunakan untuk mengukur kualitas audit. Akrual lancar sebagai proksi kualitas audit dalam penelitian ini adalah kualitas audit persepsian sehingga bukan merupakan ukuran yang akurat. 
Penelitian selanjutnya dapat mempertimbangkan menggunakan proksi yang berbeda seperti menggunakan auditor spesialis industri, spesialis perusahaan tambang, spesialis perusahaan jasa, sesuai dengan segmen (jenis) usaha perusahaan yang akan dilakukan penelitian..

2) Penelitian selanjutnya dapat mempertimbangkan untuk dilakukan penyesuaian mengenai materi pertanyaan-pertanyaan kelengkapan kertas kerja permanen dalam kuesioner yang diberikan kepada responden (Kantor Akuntan Publik) sesuai dengan segmen bisnis (jenis usaha) perusahaan baik itu perusahaan industri, perusahaan jasa, perusahaan tambang, dll.

\section{DAFTAR PUSTAKA}

Halim, Abdul. (2015). Auditing Dasar - Dasar Audit Laporan Keuangan Jilid I Edisi Kelima. Yogyakarta: UPP Akademi Manajemen Perusahaan YKPN.

Agoes, Sukrisno. (2011). Auditing Pemeriksaan Akuntan oleh Kantor Akuntan Publik. Jakarta: Fakultas Ekonomi Universitas Indonesia.

Sunyoto, Danang. (2013). Auditing Pemeriksaan Akuntan oleh Kantor Akuntan Publik. Jakarta: Fakultas Ekonomi Universitas Indonesia.

Agoes, Sukrisno., \& Hoesada, Jan. (2012). Bunga Rampai Auditing. Jakarta: Salemba Empat.

Wawi, Andi. (2010). Pengaruh Corporate Governance dan Konsentrasi Kepemilikan Terhadap Daya Informasi Akuntansi. Rachmawati, Andri., \& Triatmoko, Hanung. (2007). Analisis Faktor - Faktor yang Mempengaruhi Kualitas Laba dan Nilai Perusahaan.

Rachmawati, Andri., \& Triatmoko, Hanung. (2007). Analisis Faktor - Faktor Yang Mempengaruhi Kualitas Laba Dan Nilai Perusahaan.

Arens, Alvin, Elder., \& Randal, Beasley. (2003). Auditing and Assurance Service An Integrated Approach, Ninth Edition. New Jersey: Printice Hall.

Baridwan, Zaki., \& Hariani, Arie, Rahayu. (2010). Insentif untuk manipulasi laba sebagai syarat keefektifan audit yang berkualitas dalam mengurangi manipulasi laba. www.ssrn.com (diakses tanggal 18 Desember 2010).

Carey., \& Peter, Simnett. (2006). Audit Partner Tenure and Audit Quality. The Accounting Review.

Departemen Keuangan RI. Keputusan Menteri Keuangan Republik Indonesia Nomor 43/KMK.017/1997, Tentang Jasa Akuntan Publik.

Effendi, Arief. (2009). The Power of Good Corporate Governance, Toeri dan Implementas. Jakarta: Salemba Empat.

Giri, Ferdinan, Efraim. (2010). Pengaruh Tenure Kantor Akuntan Publik (KAP) dan Reputasi KAP terhadap Kualitas Audit : Kasus Rotasi Wajib Auditor di Indonesia.

Permana, Eka. (2012). Peranan Kertas Kerja Permanen File terhadap Laporan Audit.

Ghosh., \& Aloke, Moon, Doocheol. (2005). Auditor Tenur and Perceiptions of Audit Quality. Accounting Review, April 2005 .

Ghozali, Imam. (2001). Aplikasi Analisis Multivariat: dengan program SPSS. Semarang: Badan Penerbit Universitas Dipenogoro.

Hamonangan, Siallagan., \& Macfoedz, Mas'ud. (2006). Mekanisme Corporate Governance, Kualitas Laba dan Nilai Perusahaan.

Sukriah, Ika., Akram., \& Inapty, Adha, Biana. (2009). Pengaruh Pengalaman Kerja, Independensi, Objektifitas, Integritas dan Kompetensi Terhadap Kualitas Hasil Pemeriksaan.

Ikatan Akuntan Indonesia. (2011). Standar Profesional Akuntan Publik. Jakarta: Salemba Empat.

Nuratama, I, Putu. (2011). Pengaruh Audit Tenure, Reputasi KAP dan Komite Audit terhadap Kualitas Audit.

Jansen, M.C., \& W.H. Meckling. (1976). Theory of The Firm: Managerial Behaviour Agency Cost and Ownership Structure. Jurnal of Finance Economic. Vol 3, No. 4:304-360.

Januarti, Indira. (2009). Analisis Pengaruh Faktor Perusahaan, Kualitas Auditor, Kepemilikan Perusahaan Terhadap Penerimaan Opini Audit Going Concern (Perusahaan Manufaktur Yang Terdaftar di Bursa Efek Indonesia).

Choi, Jong-Hag., Kim, Chansog., Kim, Jeong-Bon \& Zang, Yoonseok. (2010). Audit Offize Size, Audit Quality, and Audit Pricing. Auditing: A Journal of Practice and Theory Vol 29 No. 1: 73-97.

Kementerian Keuangan RI. Keputusan Menteri Keuangan Republik Indonesia Nomor 359/KMK.06/2003 Tentang Perubahan Atas Keputusan Menteri Keuangan Nomor 423/KMK.06/2002, Tentang Jasa Akuntan Publik.

Kementrian Keuangan RI. Keputusan Menteri Keuangan Republik Indonesia Nomor 423/KMK.06/2002, Tentang Jasa Akuntan Publik.

Kementrian Keuangan RI. Keputusan Menteri Keuangan Republik Indonesia Nomor 470/KMK.017/1999, Perubahan 
KMK Nomor 43/KMK.017/1997 Tentang Jasa Akuntan Publik.

Kementrian Keuangan RI. Peraturan Menteri Keuangan Republik Indonesia Nomor 17/PMK.01/2008, Tentang Jasa Akuntan Publik.

Komalasari, Agrianti. (2004). Analisis Pengaruh Kualitas Auditor dan Proxy Going Concern Terhadap Opini Auditor. Jurnal Akuntansi dan Keuangan. Vol 9. No. 2: 1-15.

Krishnan, G,V. (2003). Audit Quality and The Pricing of Discretionary Accruals. Auditing: A Journal of Practice \& Theory, March 2003.

Manry, D.L., T.J. Mock., \& J.L. Turner. (2008). Does Increased Audit Partner Tenure Reduce Audit Quality? Journal of Accounting, Auditing \& Finance: 553-572.

Sekar, Mayangsari. (2004). Bukti Empiris Pengaruh Spesialisasi Industri Auditor Terhadap Earning Response Coefficient. Jurnal Riset Akuntansi Indonesia Vol 7 No 2, Mei.

Mulyadi. (2002). Auditing Edisi 6 Buku 1. Jakarta: Salemba Empat.

Myers, James, N., Myers, Linda, A., \& Omer, Thomas, C. (2003). Exploring the Term of the Auditor-Client Relationship and the Quality of Earnings: A Case for Mandatory Auditor Rotation?. The Accounting Review 78(3): 779-799.

Wardhani, Ratna., \& Herunata, Joseph. (2010). Karakteristik Pribadi Komite Audit dan Praktik Manajemen Laba.

Ross, A, S. (1973). The Economic Theory of Agency: The Principal's Problem. American Economics Association. Volume 63. No.2.

Sugiono.(2002). Metode Penelitian Bisnis. Cetakan ke 4. Bandung: Alfabeta.

Supriyono, R, A. (1998). Pemeriksaan Akuntan (Auditing): Faktor - Faktor yang Mempengaruhi Independensi Penampilan Akuntan Publik.

Susiana., \& Arleen, Herawaty. (2007). Analisis Pengaruh Independensi, Mekanisme Corporate Governance, Dan Kualitas Audit Terhadap Integritas Laporan Keuangan.

Agoes, Soekrisno. (2004). Pemeriksaan Akuntan oleh KAP. Buku 1. Jilid 1. Jakarta: Fakultas Ekonomi Universitas Indonesia.

Tjager, I, Nyoman., \& Alijoyo, F, Antonius. (2003). Corporate Governance: Tantangan dan Kesempatan bagi Komunitas Bisnis Indonesia. Jakarta: PT Prenhallindo.

Sekaran, Uma. (2007). Research Methods For Business. Buku 1. Jakarta: Salemba Empat.

Wibowo, Arie., \& Rossieta, Hilda. (2009). Faktor - factor Determinasi Kualitas Audit suatu studi Dengan Pendekatan Earnings Surprise Benchmark. 